\title{
A Postmodern Realism?: the struggle of narrative styles in Russell Bank's Trailerpark.
}

\author{
Óscar Ibáñez Muñoz \\ Universidad de Zaragoza
}

In an interview granted by Russell Banks in 1995, the North-American author acknowledges the fact that North-American fiction is witnessing a "useful return to realist premises"; and defines this return as "a resumption of the realist project, but informed by a period of serious self-scrutiny and practice in the experimental 60's and 70's"(89). The result of all this is a realism heavily influenced by postmodern premises which (as Banks acknowledges himself) looks rather like "something which is more formally self-conscious."

Realism and naturalism have always been somehow present in North-American literature since they were taken there from the continent in the last century. Both narrative styles have therefore been influenced by the different literary moments throughout the evolution of North-American literature. In this sense, the naturalism of Faulkner's The Sound and the Fury differs substantially from that we can see in Jack London's novels, even if it maintains the features that define it and still can be more or less easily recognised.

However, this new revival of realism and naturalism invokes, in the guise of postmodernism, a number of literary premises that are diametrically opposed to those of realism and naturalism themselves. On the one hand the essentially mimetic quality of realism is confronted by the anti-mimetism of postmodernism which postulates that the text cannot imitate reality, as there is not such reality beyond the text. On the other hand, the absolute objectivity required by realism clashes against the omnipresence of ideology claimed by postmodernism, and the determinist and mechanical world of naturalism seems to have nothing to do with the labyrinths of possibilities that chaos theory and new dynamics confer to postmodern novels.

The purpose of this paper is to delve into one of Russell Bank's novels, Trailerpark, in order to study the way in which these apparent paradoxes and contradictions are reconciled in what, in my opinion, is one of the best examples of this "self-conscious realism" Banks talks about. I will try to analyse the way in which the essentially naturalistic and realistic style of the novel has been affected by postmodern premises paying special attention to the use of metafiction, the influence of chaos theory and diverse aspects of new dynamics, and the idea of fragmentation.

Trailerpark is the name given by the American author Russell Banks to a group of short stories, all of them written before 1981 and gathered together in that very year. It's not the purpose of this essay to decide whether it is a novel or a group of short stories brought 
together, but whatever we call it, the stories of Trailerpark share a number of common thematic features that convince the reader to consider them as a unity.

Much more interesting than those shared thematic features, however, are the stylistic ones. All the stories are written in a style that uses many realistic conventions. Probably, the most noticeable one is the use of an omniscient narrator that easily peeps into the minds of the characters and describes in full detail people (the description of Flora Pease in pages 19 and 20 is only a good example of it), places (more than three pages are devoted to the description of the trailerpark and its surroundings) and even activities (ice-fishing, as well as the different procedures and tools used in it are given two full pages in the last story "The Fisher Man"). The accurateness and objectivity of the descriptions and their richness work in many cases as reality-enhancing mechanisms. This is true to such an extent that when reading the description of the little village of Catamount one feels tempted to go for a map to check whether the places exist in reality or only in fiction. This is probably due to the fact that the narrator not only gives us the name and description of the places, but also an extensive account of their history, as it is the case with Skitter Lake:

It was called Turkey Pond for over a hundred years, until Ephraim Skitter, who owned the shoe factory, left the town a large endowment for its library and a bandstand, and in gratitude the town fathers changed the name of the lake.(36)

But the most successful reality-enhancing mechanism is probably the intricate, extremely complex net that links the different stories by means of a perfectly organised display of references. Though every story in Trailerpark deals with a different owner of each of the trailers, and also with a different subject-matter, there are several events that are handled in the same recurrent way and which different characters refer to from different points of view in different stories. These events (such as Tom's suicide or Bruce Severance's murder, or simply the insinuation that Leon LaRoche might be homosexual), work not only as a thematic link for the different stories but also as the only available device for the reader to impose a cause-and-effect or lineal time structure to the book. Due to the continuous jumps in time from one story to the next (that sometimes goes back as far as to the times of the "dry-law") and to the almost absolute lack of any time references in most of the stories, these events become buoys that both enhance the realistic style of the book and provide the book with a structure.

The style of Trailerpark, however, not only moves within the sphere of realism but also, and in a more obvious way, within that of naturalism. Louis J. Budd describes naturalism as a style which "sees man as a product of his immediate environment" and which is "essentially mechanistic in its view of matter and deterministic in its attitude toward human will, moving toward theories of degeneration when viewing the individual, the family, the crowd, and finally the community itself' (65). The community of neighbours which inhabit the trailerpark are indeed the sub-product of a degenerating society. The characters of Trailerpark are, in the words of the narrator, "widows and widowers, divorcées and bachelors and retired army officers, a black man in a white society, a black woman there too, a drug dealer, a solitary child of a broken home, a drunk, a homosexual in a heterosexual society: all of them, man and woman, adult and child, basically alone in the world" (263). 
And certainly, if there is something all the people living in the trailerpark share, it is the fact that they are forsaken, disavowed by society. All the characters, with almost no exception, live in utter misery, either spiritual or economical, and more frequently both.

Besides, not only the trailerpark but the whole of the little town of Catamount seems to be ruled by a deterministic force that keeps happy those who are happy (who seem to be only those slightly cracked, as it is the case with Merle ring) and in disgrace those who were once touched by it. The narrator seems to acknowledge this fact when he describes one of the broken couples formerly living in the trailerpark:

Doreen, then, was descended from the Tiedes who had risen in the world, whereas her second cousin Buck was from the Tiedes who, generation after generation, had plowed the same old row. (81-82)

In this sense, Captain Dewy Knox's character is determined by his father's strange sense of morality, and learns that there is a right way to do things, and such is doing them as you are told to do them, no matter whether it is morally acceptable or not. That's why he goes into the army, as, on the other hand, the military boots he is given by his father as a birthday present seem to anticipate even that early. Flora Pease, the "Guinea Pig Lady" devotes her whole trailer to breed a horde of furry animals with which she tries to fill the lack of affection and care left by a broken family and a tragic childhood. Noni Hubner becomes mentally ill to the point of seeing Jesus and trying to shovel her father out of his tomb because "He tells her to do so," as a result of the pressure imposed on her by her mother, not totally sane herself, and unable to acknowledge the death of her husband. Sadness and misery stay for good in the universe of Trailerpark after they come, and sometimes they even move to the following generations.

All these realistic and naturalistic features point to the fact that one of the aims of the book is to create an accurate and objective portrait of an important part of the American society: those who have never come across the "American dream." In this sense Trailerpark is not very different from other works that had already had similar aims more than a century ago, written by people like Twain or Dickens. But there is an additional element in Banks novel that makes it substantially different from these writers: the reality that Banks tries to depict in his book is a postmodern one. As a result, many of the premises of postmodernism pass through the filters of realism and naturalism and become part of the style. Some of these premises run parallel with those of realism and naturalism, but most of them go against them, and in a sense tend to confront and undermine them. It is the case of metafiction, for example. It cannot be said that Trailerpark is a metafictional novel, but it certainly presents certain metafictional winks that work against the very basis of realism. Peter Stoicheff deals with the differences between these narrative styles in his article "The Chaos of Metafiction":

A mimetic fiction text masquerades as a copy of the world but is not. Metafiction reveals, on the other hand, how the emergent chaos of a text and of the world are one. (94)

Therefore metafiction, as a device that reveals the artificiality of the text, is essentially antimimetic, especially if its aim is to problematise the ontological matters that deal with 
the boundaries between reality and text, whereas realism is intrinsically mimetic. This mimetic masquerade vanishes, however, in different moments in the novel. In the "The Guinea Pig Lady," Bruce Severance reflects on what is happening at Flora Pease's trailer and describes it as a metaphor where Flora is God and the pigs are human beings and the trailer is the world. A metaphor which deals with the danger of over-population and the "Twilight of the gods" (46). Banks uses here one of his characters as a mouth-speaker to reveal the exact way in which his story works and the artificiality of the text becomes explicit. Something similar happens when, in this very story, and in the last one ("The Fisherman"), the narrator selects each neighbour's point of view about a matter and places them one after another in the shape of a briefing. The omniscience of the narrator is deconstructed by means of excess, to the point that the narrator even allows himself to express in more technical words what two characters, Flora and Merle, had explained in their own, plain words:

Flora Pease: Keep the animals warm, well-fed, clean and breeding. Naturally, as their numbers increase, their universe will expand. (Of course, Flora didn't express herself that way, for she would have been speaking to people who would have been confused by language like that coming for her. She said it this way: "When you take care of things, they thrive.") (59)

As a result, once more, the artificiality of the text lays bare. But the same effect can also be found in the very names of the characters: Merle RING is a man who has married almost half a dozen times; FLORA Pease bears the name of a goddess of nature in a story in which she stands as the creator and protector of a microcosm inhabited by guinea pigs; Bruce SEVERANCE is given his final severance (two bullets in his brain) when he tries to break up with his former boss, a minor drug dealer. These strange similarities (and many others that appear in other characters in the novel) between names and lives are maybe too frequent to be considered mere coincidences, and work against the realistic depiction of the characters, making them both real and fictitious at the same time.

It can be stated, therefore, that with regard to metafiction, Trailerpark can be located among those works that Patricia Waugh qualifies as "texts that manifest the symptoms of formal and ontological insecurity but allow their deconstructions to be finally recontextualised or naturalised and given a total interpretation" and which "constitute, therefore, a new realism" (19).

The self-consciousness of the text is also present in "Principles," where Claudel Bing's point of view about life is utterly changed by a story he hears in a nearby conversation in a pub. In the same way that story changes his ideology, Banks' stories aim to change our own ones as readers. Ideology is indeed a very important issue in the novel that in a sense also tends to work against realism. Realism assumes that an objective depiction of reality can be achieved, and that this depiction is neat and unmediated. Postmodernism, however, defines reality as a construction of our ideology. There are as many realities as ideologies, or, what is more, there is no reality, only ideology. Though the reality of Trailerpark is generally depicted by a single narrator, each short story deals with a different character, shows reality through different focalisers, and so what we basically find in Trailerpark are short frag- 
ments of lives but also different ways of seeing or constructing reality. Trailerpark is in many senses an account of how the people living in the trailerpark struggle in order to find a way of understanding their continuous misfortunes rather than an account of their struggle against those very misfortunes. In the short stories that open and close the novel ("The Guinea Pig Lady" and "The Fisherman") there is a moment in which the narrator stops his narration to present a detailed description of each neighbour's point of view about the central issue of the story; and there is even a story ("Principles") which is wholly devoted to describe the way in which people acquire an ideology.

It is precisely in this story that we find another postmodern feature that modifies the essentially realistic and naturalistic frame of the work. "Principles" deals with Claudel Bing's quest in search of a totalising "philosophy of life" by means of which he may be able to interpret reality. This quest, however, will fail in the end. The totalising explanation of life Claudel believes in at the beginning, according to which people are either lucky or unlucky, has no place at all in a postmodern reality. He can only find fragments, "principles" that can be applied to certain situations. Fragmentation is certainly another interesting issue in Trailerpark. After all, the novel is made up with fragments of lives, with short stories that, though aiming to create a unity, are still fragments in themselves. Even the very trailerpark as a setting, with it's individual and relatively isolated trailers, seems to reinforce the idea of a fragmented community.

The presence of fragmentation in Trailerpark calls the reader's attention to the complexity of a reality that allows no totalising explanations. The postmodern distrust towards totalising explanations of life, towards master narratives, appears also in "The Guinea Pig Lady." When Bruce Severance tells Nony Hubner about his interpretation of the problem with the pigs as a metaphor, he also makes a prediction of the eventual end of the matter: "What happens is Flora moves out, leaves the trailer to the guinea pigs. Twilight of the gods, man. God is dead. You know" $(45 ; 46)$. However, this Nietzschean prediction proves to be wrong, and, as an end to the story that results frankly unexpected and difficult to understand, it is the God-like Flora who ends up killing "her babies" herself. The postmodern reality of Trailerpark is far too complex to be reduced to a totalising interpretation, to be explained by a master narrative, however important it may be.

Among the different master narratives that are more or less obviously challenged in Trailerpark there is one in particular which is closely related to naturalism: traditional science. Naturalism is deeply rooted in the Newtonian and Darwinian assumptions of a deterministic, mechanistic universe and their confidence in their capability to predict an effect departing from any given cause. Realism as a movement, and it's own style also, responded in turn to the bourgeois arrogant belief that reality could be apprehended and universal, absolute knowledge reached. The postmodern milieu, however, moves in much more troubled (but no less interesting) waters. Postmodernism has grown up in the light of Heisenberg's uncertainty principle and Einstein's theory of relativity, and new dynamics and chaos theory have replaced the old Newtonian paradigm. This so called "new science" has also influenced the style used by Banks in his novel, and together with the mechanistic, deterministic universe imposed by naturalism there is a number of events that are only 
understandable under the light of the new scientific paradigms. Claudel Bing's decline and fall is one of them: his wife leaves the trailer's stove on during an weekend off and as a result the trailer burns to ashes, the couple go bankrupt, she leaves him for another man and he becomes a drunk and is fired from his job. The fact that such an small event brings about such huge consequences for Claudel can only be understood under the light of the "Butterfly Effect," one of the central postulates of Chaos theory, according to which there is not necessarily a lineal relationship between the importance of an effect and the magnitude of its consequences. In "Politics" we find another example of this: Nancy Hubner decides to divorce her husband and start a new life after a session with her psychiatrist. But as she is driving back home she is about to have an accident because her car slides, and this event makes her change her point of view again, and she finally stays with her husband. But the chaos that seems to rule Trailerpark from time to time is most obvious in "The Fisherman." There Merle Ring, the only owner of a trailer who doesn't care at all about money, wins at the lottery, and not once but twice.

Judging from all has been said above it can be stated that Trailerpark is a "more selfconscious" realism in the sense that, though its basic traits are realistic and naturalistic, there is a clear effort in its stories to adapt those styles to contemporary postmodern reality. Realism and naturalism are probably the most adequate styles to represent the spiritual, social and economical decadence of a neighbourhood community representative of a not small sector of American society. By means of them Banks lets his readers softly dive in his fiction, mesmerised by that "willing suspension of disbelief." But he also warns them from time to time through a number of signs that I have tried to characterise in this paper as mainly postmodern: "this is fiction," they say. "And reality is more complex than this book can reflect." It must be made clear, therefore, that Trailerpark is not an attack against realism. The postmodern features that are somehow present in the book are not purely subversive. Postmodernism, as Linda Hutcheon has explained, "uses and abuses" (12) at the same time, subverts and enhances the previous tradition. Only under the light of this postulate can Trailerpark be understood as what it is: a fine example of American "New Realism."

\section{WORKS CITED}

Banks, Russell. Trailerpark. New York: Ballantine Books, 1986.

Budd, Louis J. "The American Background." The Cambridge Companion to American Realism and Naturalism. Ed. Donald Pizer. New York: CUP, 1995.

Collado, Francisco. "Back to Realist Grounds: An Interview with Russell Banks." Revista de Estudios Norteamericanos, 4 (1995): 89-98.

Hutcheon, Linda. A poetics of Postmodernism: History, Theory, Fiction. New York \& London: Routledge, 1988

Stoicheff, Peter. "The Chaos of Metafiction." Chaos and Order. Complex Dynamics in Literature and Science. Ed. N. Katherine Hayles. Chicago \& London: The U of Chicago P, 1991.

Waugh, Patricia. Metafiction. The Theory and Practice of Self-Conscious Fiction. New York \& London: Routledge, 1988. 